6. Mahler Gustav Electronic Jewish Encyclopedia. [Electronic resource]. Retrieved from http://eleven.co.il/article/12592 (12.09.2018) [in Russian].

7. Miheeva, L.V. (1972). G. Mahler. Brief Essay on Life and Creativity. Leningrad: Muzyka [in Russian].

8. Neboljubova, L.S. (1990). Musical culture of Germany and Austria at the turn of the XIX - XX centuries: G. Mahler, R. Strauss. Kyjiv: Muzychna Ukrajina [in Russian].

9. Rozenshil'd, K.G. (1975). Mahler: from the history of the twentieth century. Moskva: Muzyka [in Russian].

10. Sollertinskij, I.I. (1963). Symphonies by H. Mahler. Istoricheskie jetjudy, 334 [in Russian].

UDC 78.083;785.1

DOI $10.33287 / 221912$

Золотарьова Наталья Сергіївна, кандидат мистецтвознавства, дочент кафедри „,Фортепіано” Дніпропетровської академії музики ім. М. Глінки тел. (097) 374 - 44 - 25 e-mail: nzpianist1212@gmail.com

Оліферовська Тетяна Олександрівна, магістрант кафедри „Оркестрові інструменти” Дніпропетровської академії музики ім. М. Глінки тел. (095) 806 - 65 - 77 e-mail: tarantanya1995@gmail.com

\title{
ВПЛИВ ВИКОНАВСЬКОЇ ШКОЛИ НА ІНТЕРПРЕТАЦЮ ТВОРУ (на прикладі віолончельного концерту А. Дворжака)
}

Мета статті - проаналізувати варіантно можливі версії щодо інтерпретацій концерту для віолончелі 3 оркестром h-moll op. 104 Антоніна Дворжака, їх походження і вплив на манеру виконання. За приклад представлені московська та ленінградська віолончельні виконавські школи Семена Козолупова та Олександра Штримера, що являють собою різну прихильність до засобів трактовки та інтерпретації. Найбільш колоритними та протилежними 3 питання 
художнього тлумачення, на наш погляд, $\epsilon$ такі представники виконавських шкіл як Мстислав Ростропович - представник школи Семена Козолупова та Даниїл Шафран - виразник творчого напряму Олександра Штримера. Зазначені віолончелісти цікаві не тільки яскравою відмінністю бачення інтерпретацій творів, а й тим, що вони доклали немало зусиль у популяризації інструмента і вивели його на один рівень зі скрипкою та фортепіано, як сольного. Методи дослідження являють використання історичного, емпіричного, практичного, інтерпретаційно-порівняльного підходів, що зумовлено обгрунтуванням та розглядом виконавських версій через призму впливу педагогічних шкіл на аспекти художньо-технологічного плану. Наукова новизна статті полягає у порівнянні інтерпретаційних версій концерту для віолончелі А. Дворжака h-moll op. 104 у виконанні радянських віолончелістів Мстислава Ростроповича та Даниїла Шафрана, з точки зору впливу школи на технічні прийоми та художнє бачення твору, який є прикладом, у своєму жанрі, найяскравіших поєднань глибокого ліризму, драматизму та потребує віртуозного володіння інструментом. Це один 3 небагатьох улюблених солістами віолончельних концертів епохи Романтизму. Таким чином у ньому міститься широке підгрунтя для інтерпретаційного аналізу. Висновки. Порівняння інтерпретаційних версій, як метод виконавського аналізу, сприяє яскравому відображенню художньо-образного змісту твору, допомагає знайти свій власний стиль, синтезуючі вже використані технічні та агогічні прийоми гри з новими художніми баченнями.

Ключові слова: виконавська школа, інтерпретація, технічні прийоми, концерт для віолончелі.

Золотарёва Наталья Сергеевна, кандидат искусствоведения, доцент кафедры „Фортепиано” Днепропетровской академии музыки им. М. Глинки

Олиферовская Татьяна Александровна, магистрант кафедры „Оркестровые инструменты” Днепропетровской академии музыки им. М. Глинки

Влияние исполнительской школы на интерпретацию произведения (на примере виолончельного концерта А. Дворжака)

Цель статьи - проанализировать вариантно возможные интерпретационные версии концерта для виолончели с оркестром 
h-moll op. 104 Антонина Дворжака, их происхождение и влияние на манеру исполнения. За пример представлены московская и ленинградская школы Семена Козолупова и Александра Штримера, что являют собой категорически разную приверженность к средствам трактовки и интерпретации. Наиболее колоритными и противоположными в вопросах трактовки есть Мстислав Ростропович - представитель школы Семена Козолупова и Даниил Шафран - последователь Александра Штримера. Представленные виолончелисты интересны не только ярким отличием вйденья трактовки и интерпретаций произведений, но и тем, что они приложили не мало усилий в популяризации инструмента и вывели его на уровень со скрипкой и фортепиано, как сольного. Методы исследования заключается в использовании исторического, эмпирического, практического, интерпретационно-сравнительного подходов, что обусловлено обоснованием и рассмотрением исполнительских версий через призму влияния педагогических школ на аспекты художественно-технологического плана. Научная новизна заключается в сравнении интерпретационных версий концерта для виолончели А. Дворжака h-moll op. 104 в исполнении советских виолончелистов Мстислава Ростроповича и Даниила Шафрана, с точки зрения влияния школы на технические приёмы и художественное вѝдение произведения, которое является примером, в своём жанре, ярких сочетаний глубокого лиризма, драматизма и требует виртуозного владения инструментом. Это один из не многих любимых солистами виолончельных концертов эпохи Романтизма. Таким образом, в нем содержится широкое основание для интерпретационного анализа. Выводы. Сравнение интерпретационных версий, как метод исполнительского анализа, способствует яркому отображению художественно-образного содержания произведения, помогает найти свой собственный стиль, синтезирующий уже использованые технические и агогические приемы игры с новыми художественными взглядами.

Ключевые слова: исполнительская школа, интерпретация, технические приёмы, концерт для виолончели.

Zolotareva Natalia, Ph.D. in Art History, associate professor of the department „Piano” of M. Glinka Dnipropetrovsk academy of music

Oliferovskaya Tatyana, master student of the chair „Orchestral instruments" of M. Glinka Dnipropetrovsk academy of music 
The influence of performance school to interpretation of masterpiece (on the example of A. Dvorak's cello concert)

The purpose of this article is analysis of possible versions concerning the interpretation of the Antonin Dvorak's concert for cello with orchestra, h-moll or. 104, their origin and influence on the manner of performance. Moscow and Leningrad schools are taken as an example. Schools of S. Kozolupov and O. Strimer represent vividly different views on means of theory and interpretation. In my opinion, the most colorful and controversial on the matter of interpretation are the following representatives of the music schools: $\mathrm{M}$. Rostropovich as a representative of the S. Kozolupov views and D. Shafran for O. Strimer school. These cellists are interesting not only because of their vivid difference in the vision of theory and interpretations of music works, but also by the fact that they have made a lot of effort to popularize the cello and bring it to the level of solo instrument as high as the violin and piano. The methods of this research consist of historical, empirical, practical, interpretivecomparative approaches, which are based on examination of performance versions through the prism of the pedagogical schools influence on the aspects of the art-technological plan. The scientific novelty consists in the lack of material on the comparison of interpretative versions of the concert for cello A. Dvorak h-moll op. 104 performed by Soviet cellists Mstislav Rostropovich and Daniil Shafran, in terms of the influence of "school" on technical techniques and artistic vision of the work, which is considered as an example, in his genre, of the most striking combinations of deep lyricism, drama and the need for a masterly skills of instrument proficiency. It's one of a few favorite concerts of the Romantic era among the soloists of cello. Thus, it contains a broad background for an interpretative analysis. Conclusions. Comparison of interpretative versions, as a method of performing analysis contributes to a vivid representation of the artistic content of the work, helps to find its own style combining already used technical and agogic techniques of the performance with new artistic views.

The key words: performing school, interpretation, technical techniques, concert for cello.

Постановка проблеми. Питання інтерпретації музичних творів містить у собі глибоку проблему та викликає безліч суперечок. У першу чергу це стосується не тільки студентів (бо нерідко саме індивідуальне бачення твору, інтерпретація є критерієм оцінювання 
музичного виконання, хоча це й досить суб'єктивне поняття), а й видатних музикантів. Також манера гри невід'ємно пов'язана зі створенням колективів, ансамблів тощо.

Таким чином, формування та развиток виконавських шкіл, насамперед, залежить від індивідуального відчуття митцем віяння сучасних тенденцій та традицій. 3 рештою, у процесі развитку комунікацій, неможливо уникнути синтезу показових рис, притаманних різностороннім представникам. Саме тому сучасному світові важко чітко визначити рамки належності до певної виконавської школи. Сформований музикант, безперечно, посилається на основні традиції свого музичного коріння. Виходячи iз цього, у виконанні одного й того ж музичного матеріалу можна виділити професійні методи та принципи педагога, що має належність до тієї або іншої виконавської школи.

Актуальність дослідження визначається тим, що в історії віолончельного мистецтва $є$ чимало праць присвячених методології гри та рішенню технічних проблем - автори Даго Рінар і Хуго Беккер, Олексій Лазько, Лев Гінзбург, але ж поглиблення в питання інтерпретації, а тим більш порівняння гри Даниїла Шафрана та Мстислава Ростроповича у професійній музичній літературі не зустрічається.

Мета дослідження виявити та обгрунтувати відмінні художньообразні, технологічні та імпровізаційні тенденції Д. Шафрана та М. Ростроповича у контексті впливу виконавської школи на прикладі концерту для віолончелі h-moll op. 104 Антоніна Дворжака.

Огляд літератури. Особистість А. Дворжака завжди збуджувала неабиякий інтерес музикознавців. Їхня увага була зосереджена на епістолярній спадщині композитора, життєвому i творчому шляху майстра (3. Гулінська, В. Сгорова, О. Лазько, I. Белза). Техниці виконання деяких творів присвячені аналітичні роботи Х. Беккера [3], О. Лазько [10], Л. Гінзбурга [5] та ін. Але ж художньо-виконавська своєрідність інтерпретаційного бачення означеного твору вищевказаними віолончелістами залишається ще маловивченою.

Об'єкт дослідження - віолончельне виконавство у контексті феномену професійних виконавських шкіл, а предмет - специфіка інтерпретаційних виконавських версій концерту для віолончелі h-moll op. 104 Антоніна Дворжака, представлених видатними віолончелістами Д. Шафраним і М. Ростроповичем. 
Виклад основного матеріалу. Характеризуючи стиль виконання та тенденції інтерпретації віолончельного шедевру Д. Шафраном та М. Ростроповичем слід підкреслити те, що їхнє творче життя набуло обертів у історично сформованих вагомих центрах музичного буття. Неможливо заперечити той факт, що яскравими представниками даних виконавських шкіл $\epsilon$ багато талановитих музикантів: С. Кнушевитський, О. Власов, Б. Пергаменщиков, В. Берлінський та багато ін.

На той час одним 3 найважливіших центрів розвитку світової музичної культури була Московська консерваторія ім. П.І. Чайковського, в якій клас віолончелі очолював Семен Матвійович Козолупов. Серед його випускників - ряд виконавців, які виступали та виступають на всесвітньо відомих сценах: Н. Шаховська, Н. Гутман, Б. Пергаменщиков, I. Монігетті, але ж найяскравішим з них був Мстислав Леопольдович Ростропович.

Характерною рисою московської виконавської школи постають витончені технічні прийоми правої руки, сильний, глибокий звук, віртуозне володіння дрібною моторикою та артикуляційними можливостями лівої руки: „В юності Мстислава Леопольдовича захоплювала гротескна гострота ритмічного малюнку, деяка жорсткість у передачі емоцій. Експресивність гри, натиск придушували у нього красу ліричних образів. Різні аспекти душевних переживань розкривались їм під час односторонньо, недоречно. Часом виконавець немов прагнув піти від простих душевних роздумів у нестримний потік миттєвих життєвих вражень" $[6,46],-$ зазначала Софія Хентова у своїй роботі присвяченій життю i творчості М. Ростроповича.

Наряду з поглядами московської виконавської школи Семена Козолупова, протележні традиції закріпились у ленінградській Олександра Штримера. Останній не надавав значення місцю де виконується твір. Згідно з його думкою, звук повинен бути легким, без зайвого тиску на інструмент й надання будь-яких фізичних зусиль. Та, якщо виходити 3 акустичних можливостей концертних приміщень, слід приділити увагу так званій „роботі на зал”, а саме, перебільшення сили звучання нюансів, виразна артикуляція як лівої, так і правої рук і т.ін.

Як це не дивно, у багатьох статтях йдеться про те, що відношення Д. Шафрана до московської виконавської віолончельної школи було досить неурівноваженим. Віолончеліст вважав, що школа 
С. Козолупова приділяє більше уваги технічній основі майстерності, а в той же час, школа О. Штримера у Ленінграді, не втрачаючи важливість техніки виконання, в більшій мірі приділяла увагу питанням інтерпретації, разкриття стилістичного розмаїття музики, розвиваючи творчу індивідуальність вихованців.

Незважаючи на зазначену позицію О. Івашкін у своїй роботі про Д. Шафрана пише, що знаходячись у Москві віолончеліст виділив для себе ряд нових технічних виконавських моментів. Такими прийомами гри були: використання так званого „білого звуку” (техніка лівої руки, що характеризується відмовою від вібрації). Але, згідно 3 багатьма фактами i дослідженнями, представлене поняття $\epsilon$ характерним саме для виконавської школи О. Штримера. Та наступне твердження О. Івашкіна займає вагоме місце у ролі шкіл щодо характера манери гри Д. Шафрана: „спостереження за грою віолончелістів так званої московської школи призводять Шафрана до перегляду багатьох творчих поглядів. Тепер його починає залучати більш вагома, матеріальна манера гри, широке мелодійне дихання, яскравість і визначеність драматургії, масштаб виконання" [4, 8].

На жаль, у музичній літературі, що вивчає віолончельне мистецтво, мало зазначено щодо порівняння ігрових тенденцій цих визначних, єдиних за походженням та протилежних за темпераментом виконавців. Справа у тому, що М. Росторопович та Д. Шафран дали величезний поштовх i вивели на новий рівень віолончельну музику. Ці музиканти не мали наміру створити власну школу як це зробили не менш відомі віолончелісти, такі як: Д. Поппер, Б. Ромберг, Ж. Дюпор, Р. Сапожніков, І. Волчков, К. Давидов. На творах цих митців вчились та вчаться віолончелісти від минулого до сьогодення, набуваючи технічних та виконавських навичок в усьому світі, незалежно від перспективи та рівня освіти.

Внесок М. Ростроповича та Д. Шафрана як виконавців, в історії віолончельного мистецтва формується в абсолютно нових знахідках щодо прояву інструмента, насамперед, як сольного. Про зазначене цікаво написано у роботі Е. Уілсон, присвяченій Ростроповичу: „Можна сказати, що, вирішуючи завдання, поставлені кращими композиторами того часу, він заново винайшов гру на віолончелі - до такої міри, що коли В. Лютославський оголосив про початок роботи над концертом для віолончелі, Ростропович сказав йому «не думайте про віолончель, віолончель - це я»" $[5,8]$. 
Про мову виконання Д. Шафрана дуже точно писав знаний скрипаль, музикознавець, педагог І. Ямпольський: „Артист належить до рідкісних інструменталістів, сила гри яких полягає не в спритності пальців, не у красі видобутих із інструмента звуків, а в живому творчому інтонуванні музики. Я чув віолончелістів з більш потужним і більш красивим за зовнішніми показниками тоном, ніж у Шафрана, та рідко такий своєрідний і неповторний по тембру звук віолончелі. На ньому, як і на усьому, до чого $б$ не торкався артист, лежить печатка індивидуального. Його звук одразу ж відмічаєш за якимось, тільки йому властивому, колориту обертонової підоснови” [7, 34].

Цікавий факт, що в роки студентства, а саме у 1950-му році у Празі, вони розділили першу премію граючи концерт А. Дворжака h-moll на конкурсі ім. Г. Вігана. Слід зазначити, що Гануш Віган був одним із засновників відомого „Чеського квартета”, в якому грав із зятем А. Дворжака, скрипалем Й. Суком, а також був близьким другом композитора. Особисто Ганушу i був присвячений грандіозний концерт для віолончелі ор. 104.

Концерт для віолончелі з оркестром h-moll op. 104 складається 3 трьох частин. Та на відміну від популярних концертів Е. Лало, К. Сен-Санса, Р. Шумана, концерт відкриває розгорнутий оркестровий вступ, представляючи провідний музичний матеріал першої частини Allegro, що написана в сонатній формі. Тема головної партії звучить приховано, ніби здалеку, але 3 кожною фразою розширюється фактура й динаміка, i, таким чином, поступово розростається. Вона має героїчний, життєстверджуючий характер, звучить рішуче, а хід на чисту кварту в середині головної партії передає заклик, подібно гімну. Тут А. Дворжак звертається до пісень та бойових гімнів гуситських воїнів. Саме ця тема трансформується і стає основою у фіналі.

Друга частина Adagio ma non troppo написана у складній тричастинній формі близької до пісенної. Пасторальний, умиротворений характер вступу нагадує картину природи, можливо це замальовка ранку в Високій (місце де А. Дворжак так любив бути й творити): „В муках народжувався цей твір. Дворжак писав його уривками, буквально примушуючи себе: - «Якби я міг працювати так безтурботно, як у Високій, я б вже давно його закінчив», - писав він у Прагу. 15 січня 1895 року повідомив, що завершує фінал, але й після цього ще провозився майже місяць” [5, 27]. 
Для цієї частини характерні раптові зміни характеру, спокійна і розспівна ідилія переривається спадними секундовими інтонаціями, які нагадують благаючі ридання з придихами у крайніх частинах. У середньому розділі особливий інтерес викликає цитування мелодії пісні „Залиш мене саму” із циклу „Чотири пісні” ор. 82 (1888). Це своєрідна епітафія своєму першому коханню. Адже, за словами Й. Сука, саме ця пісня особливо подобалась Йозефіні Чермакрвій. Також, після іiі смерті, пісня була включена і у фінал Концерту для віолончелі op. 104 h-moll. Закінчується друга частина розміреним, завмираючим ходом вгору і поступовим спадом 3 укрупненням тривалостей. Мелодія повисає на терції викладеної флажолетами.

Фінал Allegro moderato написаний у формі рондо. Вступ починається ніби здалеку, прихованим, це яскраво передається піццикатто у струнних. Рефрен побудований фактично на матеріалі головної партії першої частини у видозміненому вигляді, причому героїчний, життєстверджуючий характер не тільки зберігся, а й набув рис танцювальності. Початок першого епізоду підхоплює характер рефрену, це найбільш тематично різноманітний розділ. За танцювальністю йде героїка, потім лірико-гармонійна своєрідність у віртуозному збагаченні. Невеликий каденційний мотив драматичного характеру призводить до рефрену, але вже на $p p$. Наступний епізод $\epsilon$ лірико-драматичним центром концерту. Вперше у цій частині з'являється спокійний темп Andante, мелодійна лінія співуча, розвивається хвилеподібно. Штиль триває досить довго, поступово розростаються стрімкі пасажі. Досить тихий нюанс витримується аж до дуету із солюючої скрипкою.

Своєрідним переможним результатом є завершальне проведення рефрену в однойменному мажорі. Ця тема за емоційним напруженням несе у собі всі ознаки коди (тонічна гармонія, наявність завершуючого звороту), за великим рахунком, на цьому можна було б й закінчити. Але Дворжак пише розгорнуту коду, яка відрізняється від типової, й тієї, яку він писав у першій частині. Тут немає характерного ущільнення фактури, емоційного вибуху, громогласної динаміки, збільшення темпу, а все зовсім навпаки. У коді композитор розкриває найкращі темброві можливості інструмента, насиченість та колорит його регістрових барв.

Так само важливу роль грає оркестр, який гармонійно перекликається 3 віолончеллю, пропускаючи i вислуховуючи ii репліки, а, де потрібно, підтримуючи. Соло скрипки сприймається як 
щось піднесене, можливо, це людська душа здійснює останній політ над тілесним світом. Віолончель доповнює мелодію, але дуетом це назвати складно, так як інструменти говорять про одне, але ніби не чують один одного.

Головними новаторськими аспектами композиторського письма у концерті для віолончелі 3 оркестром h-moll op. 104 є написання віртуозного циклу без втрати реалізації високохудожніх цілей; А. Дворжак першим у сольній репертуарній спадщині пише таку розгорнуту коду; також розмаїття монотематизму, широке включення інструментальних речитативів та діалогів, вдала спроба написати концерт-симфонію для солюючої віолончелі, як через століття це зробить С. Прокоф’єв.

В інтерпретації Даниїла Шафрана головна партія вступу звучить доволі імпровізаційно вільно, через те, що темп виконавця трохи стриманіший ніж в оркестровому вступі. Але цей момент виправданий самим композитором (Quasi improvisando). У головній темі через ,зламане виконання" аккордів, відмічається сухість звучання матеріалу, що також можна простежити у розділі a tempo, що зумовлено перехопленням смичка. Однією 3 технологічних складностей є збереження мелодійної лінії верхнього голосу. Також своєрідним та індивідуальним питанням $є$ вибір редакції штрихів епізоду шістнадцятих. Важливо підкреслити танцювальність шляхом артикуляційних прийомів правої руки, а саме виконання несиметричних штрихів (складність полягає у максимально ритмічному виконанні). В обох варіантах це перша редакція Григорія Пеккера, хоча манера гри Даніїла Шафрана схильна до максимальної гладкості, він майже не відділяє останню шістнадцяту. Зв'язуюча партія агогічно рельєфна та ритмічно вільна. Кожна фраза не є продовженням, а ніби заново зароджується. Виконавець доволі сміливо використовує витриману тиху динаміку, що зумовлено специфікою поглядів школи Олександра Штримера. Фрази питання та відповіді у побочній партії відтіняються за допомогою тембрових варіацій та закінченням фраз флажолетом на іншій струні, цей прийом звучить тендітно та утаємничено (хоча досить рідко зустрічається в інтерпретаціях, та є проявом суто індивідуального стилю гри соліста). У розробці важливу драматичну роль грає епізод animato, це своєрідний діалог соліста 3 оркестром, що підтверджується чергуванням проведення мелодії та акомпанементу. Цікавим моментом є драматично підкреслені, продумані агогічні 
коливання та використання різних видів вібрато (від ліктьового до плечового). Підхід до кульмінації виконується способом динамічного наростання по двутактам. Таким чином, можна виявити поділ тематичного матеріалу на підтеми, які виділяються переважно динамічними варіаціями. Рішучий характер побічної партії у репризі підкреслює яскравий тембр відкритих струн, хоча це може завадити логічному фразуванню, через ризик занадто різкого звучання. Кода Piu mosso у розумінні соліста передає переможній характер, що додається стрімким темповим наростанням та віртуозним подоланням технічних труднощів стосовно гри подвійних нот у високих позиціях. Відтак, вплив виконавської школи знаходить своє відображення у досить вільній трактовці темпових i динамічних контрастів та непередбачуваності агогічних відхилень.

На відміну від Д. Шафрана, М. Ростропович перші акорди грає по трьом струнам одночасно, це має масштабне та об'ємне звучання. У таких, на перший погляд, незначних деталях й проявляється сутність школи. Головна партія майже не досягає нюансу $p$, що надає їй вольового настрою. 3 виконавської точки зору тривале використання нюансу $f$ потребує великих фізичних зусиль, що не завжди можна досягнути тільки репетиціями, найчастіше це $\epsilon$ вродженим показником. Данне вважається однією 3 основних показових рис московської виконавської школи. Побічна партія звучить агогічно стримано та у радісному ключі. Драматизм епізоду animato підкреслюється грою із „розкачкою”, починаючи 3 pp, цей фрагмент, за трактовкою М. Ростроповича, є „тихою кульмінацією” усього концерту. Цікавим постає бачення теми 3 коди. Д. Шафран майже не виділяє іiі останнє проведення та створює враження безперервного руху до останнього акорду. У Ростроповича стійко фіксується цей мотив, не втрачаючи нещадного руху до фінального акорду першої частини, що підкреслюється не стільки стрімкістю accelerando, а й гучністю та широтою смичка.

Вступ до другої частини малює колорит чеської пасторалі. Яскраво і точно цей характер передає М. Ростропович у першому розділі, м'яко та прозоро, майже без вібрато повторюючи тему оркестра. Манера його виконання поглиблює в образну сферу Біблійних сюжетів. Д. Шафран цю тему грає більш експресивно, 3 інтенсивною вібрацією та глибокою емоційною наповненістю. Низхідні інтонації дещо відхилені від ритму, а динамічні висоти інтерпретатор підкреслює додатковим accelerando. Каденція у 
середині частини виконана виключно самобутньо і віртуозно, що випромінює пристрасть людини до життя. Прехід до середини твору має особливо цікаву аплікатуру: кінцівки фраз виконуються у високих позиціях ставки на низьких струнах, що дуже рідко використовується навіть великими віртуозами. М. Ростропович, напроти, суворо дотримується задуму композитора, не виходячи за темпові та динамічні рамки; грає тембральними можливостями інструмента й їх різновидами, широко використовує „білий звук”.

Таким чином, прочитання виконавцями уособлення художнього задуму частини має протилежні сторони. М. Ростропович своєю стриманою грою переносить слухача у світ трансцендентного, змушує задуматись щодо простих істин. Тоді як Д. Шафран ніби розкриває специфіку життя та описує почуття людини такими, як вони $\epsilon$, у драматично напружених епізодах підсилюючи фарби виконавськими прийомами, наприклад glissando та „вібруючою рукою".

У фіналі концерта Д. Шафран проявляє всі свої неповторні віртуозні можливості, що підкреслює танцювальний характер частини. Своєрідною є трактовка шістнадцятих, швидке виконання котрих виводить їх на рівень групетто. Ці моменти допомагають відобразити танцювальний задум, але інколи пригнічують жанрові риси маршових епізодів. Віртуозна гра 3 виразним accelerando в епізоді Meno mosso, відтворює картину польоту. Кода насичена глибоким тембром з відчуттям любування інструментом. Кожну ноту виконавець починає затримуючи вібрато, в місцях tutti однорідно зливається 3 оркестром, сольні епізоди звучать бережно й лагідно. Так лірично, танцювально, а де інде пристрасно й пафосно звучить концерт А. Дворжака для віолончелі 3 оркестром h-moll видатного романтика свого часу Даніїла Шафрана.

Третя частина концерта у виконанні М. Ростроповича $\epsilon$ своєрідним еталоном інтерпретаційних варіантів. Основна тема має життєстверджуючий характер, що досягається штрихом деташе згладжуючи кожен звук у нюансі $f$. Акорди виконуються стабільно на трьох струнах одночасно. Завершує епизод невелика каденція, яку М. Ростропович виконує достатньо зібрано за характером i динамікою, не втрачаючи свободи. Друге проведення теми рефрену звучить ніби здалеку, як спогад. Епізод Moderato М. Ростропович виконує стримано, та менш емоційно і збуджено ніж Д. Шафран. 
Останнє проведення рефрену має масштабне, затверджене значення, без зайвих прискорень.

Кода сприймається як постлюдія, реплики віолончелі звучать незбагненно ніжно та душевно, зберігають наспівний характер, який $\epsilon$ близьким до віртуозної оперної арії колоратурного сопрано. Настрій коди підкреслює вокальна природа прийому вібрато. Виконання М. Ростроповича виділяється особливістю, присутній далеко не у всіх солістів, це, насамперед, простоти і ясності трактовки, передбачуваності, стриманості. Адже темпові відхилення часто зумовлені нюансуванням (входячи в образ твору, під впливом емоцій важко не прискорити на crescendo та на $p$ навпаки). Така виконавська манера дає можливість цілісному поєднанню соліста 3 оркестром. Чого взагалі не можна сказати про манеру гри Д. Шафрана, бо його інтерпретації завжди непередбачувані та неповторні.

Висновки. На підставі проведеного аналізу виконавських інтерпретаційних версій треба зазначити, що важливим для самобутнього вираження художнього змісту концерту для віолончелі h-moll $\epsilon$ логіка підбору технічних виконавських аспектів. До них належить вибір аплікатурних варіантів у цілях максимально точного розкриття запланованих емоційно-образних картин, що підкреслюється в опорі на запропоновані редакцією артикуляційноштрихові варіанти. Вдалий підбір музично-естетичних i технологічних прийомів допомагає поглибити слухача в епоху та драматичний задум композитора.

Таким чином, вплив московської школи знаходить своє відображення у монументальності музичного висловлювання, глибині та силі звучання й досить чіткого дотримання метро-ритмічних i темпових вказівок. Ці моменти можна прослідкувати й у наступників М. Ростроповича, таких як Л. Свграфов, Н. Шаховська (професори Московської консерваторії ім. П.І. Чайковського). Щодо традиційних рис ленінградської виконавської школи, слід виділити піднесення індивідуальності та самобутності виконавця, сміливість інтерпретацій як спосіб самовираження, акцентування віртуозного початку. Серед учнів О. Штримера, які отримали визнання не тільки як виконавці, композитор Ю. Фалік, а також музичний дослідник, автор багатьох праць присвячених історії віолончельного мистетства О. Лазько.

Взагалі, не має підстав засуджувати ту або іншу інтерпретацію, якщо вона має обгрунтований сенс. Треба додати, що базис трактовки, безперечно, зумовлений школою гри. Так або інакше, але 
цей факт має велику роль і його необхідно завжди виділяти, особливо під час гри на майстер-класах та участі у конкурсах. Адже дуже важливо враховувати, до якої виконавської школи належить Вчитель або член журі. Цей момент напряму пов'язаний із продуктивністю мистецьких заходів, спрямованих на розвиток творчого потенціалу.

Перспективи дослідження представленої проблеми полягають у здійсненні виконавського аналізу інших творів-шедеврів віолончельної музики в контексті їх виконавської інтерпретації відомими віолончелістами сьогодення.

\section{Список використаних джерел і літератури:}

1. Афанасьева О. Мстислав Ростропович. Любовь с виолончелью в руках. Москва: Алгоритм, 2015. 75 с.

2. Беккер Х., Рина Д. Техника и искусство игры на виолончели. Москва: Музыка, 1978. 285 с.

3. Гинзбург Л. История виолончельного искусства. К. IV. Москва: Музыка, $1978.407 \mathrm{c}$.

4. Гулинская 3. Антонин Дворжак. Москва: Музыка, 1973. 37 с.

5. Егорова В. Антонин Дворжак: Монография. Москва: Музыка. 1997. 617 с.

6. Козолупова Г. Жизнь и творчество С. Козолупова. Москва: Музыка, 1986. $128 \mathrm{c}$.

7. Ивашкин А. Даниил Шафран. Москва: Музыка, 1980. 32 с.

8. Уильсон Э. Мстислав Ростропович: учитель, легенда. Москва: Эсмо, 2011. $531 \mathrm{c}$.

9. Хентова С. Ростропович. Санкт-Петербург: Культ-информпресс, 1993. 303 с. 10. Ямпольский И. Даниил Шафран. Москва: Советский композитор, 1974. 71 с.

\section{References:}

1. Afanas'eva, O. (2015). Mstislav Rostropovich. Love with a cello in their hands. Moskva: Algoritm [in Russian].

2. Bekker, H., Rina, D. (1978). Technique and art of playing the cello. Moskva: Muzyka [in Russian].

3. Ginzburg, L. (1978). History of cello art. B. 4. Moskva: Muzyka [in Russian].

4. Gulinskaja, Z. (1973). Antonin Dvorak. Moskva: Muzyka [in Russian].

5. Egorova, V. (1997). Antonin Dvorak: Monograph. Moskva: Muzyka [in Russian].

6. Kozolupova, G. (1986). The life and work of S. Kozolupov. Moskva: Muzyka [in Russian].

7. Ivashkin, A. (1980). Daniel Shafran. Moskva: Muzyka [in Russian]. 
8. Uil'son, Je. (2011). Mstislav Rostropovich: teacher, legend. Moskva: Jesmo [in Russian].

9. Hentova, S. (1993). Rostropovich. Sankt-Peterburg: Kul't-informpress [in Russian].

10. Jampol'skij, I. (1974). Daniel Shafran. Moskva: Sovetskij kompozitor [in Russian].

UDC 78.08; 78.2

DOI $10.33287 / 221913$

\begin{abstract}
Shchitova Svitlana Ph.D., Associate Professor, Head of ,History and Theory of Music” chair of M. Glinka Dnipropetrovsk Academy of music тел. (093) 151 - 99 - 81 e-mail: shchitova@i.ua
\end{abstract}

Yakimets Alexander Master of ,Academic singing” chair of M. Glinka Dnipropetrovsk Academy of music тел. (066) 625 - 56 - 58 e-mail: Yakimets1754@ukr.net

\title{
THE INNOVATIVE INTERPRETATION OF THE CHAMBER-VOCAL GENRE IN THE LATE WORKS OF SCHUBERT
}

The purpose of the study is to prove the innovative approaches of F. Schubert in vocal works on the example of his later opuses - the vocal cycle „Winterreise”, op. 90 (,Winter Road”) and the song collection „Der Schwanengesang” (,Swan Song”). The methods of this proposed scientific article are based on the research approaches (historical, compare, analytical), which allow to us to follow the path of dramatization of the song in the late works of F. Schubert, as well as to determine the conformity of the vocal intonation to the poetic text. The material of scientific intelligence there are ten separate songs, namely, five songs from the vocal cycle ,Winter Path" and five songs on the lyrics by G. Heine from the collection ,Swan Song”. In our opinion, they are not only indicative, but also similar in form, methods and content. The scientific 